\title{
Contributions of Subjective Well-Being and Good Living to the Contemporary Development of the Notion of Sustainable Human Development
}

\author{
Romel Ramón González-Díaz ${ }^{1}$ [, Ángel Acevedo-Duque ${ }^{2, *}$, , Guido Salazar-Sepúlveda $^{3}$ and Dante Castillo ${ }^{4}$ \\ 1 Centro Internacional de Investigación y Desarrollo (CIID), Monteria 230001, Colombia; director@ciid.com.co \\ 2 Faculty of Business and Administration, Public Policy Observatory, Universidad Autónoma de Chile, \\ Santiago 7500912, Chile \\ 3 Departamento de Ingeniería Industrial, Facultad de Ingeniería, Universidad Católica de la Santísima \\ Concepción, Concepción 4090541, Chile; gsalazar@ucsc.cl \\ 4 Faculty of Humanities, Psychology School, Universidad de Santiago de Chile, Santiago 9170020, Chile; \\ dante.castillo@usach.cl \\ * Correspondence:angel.acevedo@uautonoma.cl
}

\section{check for} updates

Citation: González-Díaz, R.R.; Acevedo-Duque, Á.;

Salazar-Sepúlveda, G.; Castillo, D. Contributions of Subjective

Well-Being and Good Living to the Contemporary Development of the Notion of Sustainable Human Development. Sustainability 2021, 13, 3298. https://doi.org/10.3390/ su13063298

Academic Editor: Fanli Jia

Received: 18 February 2021

Accepted: 7 March 2021

Published: 17 March 2021

Publisher's Note: MDPI stays neutral with regard to jurisdictional claims in published maps and institutional affiliations.

Copyright: (c) 2021 by the authors. Licensee MDPI, Basel, Switzerland. This article is an open access article distributed under the terms and conditions of the Creative Commons Attribution (CC BY) license (https:/ / creativecommons.org/licenses/by/ $4.0 /)$.

\begin{abstract}
The article analyzes the contributions of the notions of Good Living attributable to epistemologies, traditions, and subjective well-being at work, given the current changes in the working context, to enrich the concept of human development. The article is developed with an analyticaldescriptive and synthetic approach, reconstructing the concept of Good Living through a theoreticaleconomic, ontological, and epistemological comparison and its dimensional axes. Methodologically, a systematic review of human development literature is used in Latin America through the Web of Science (WOS), comparing the UNDP Technical Notes (HDI) with the various approaches to Good Living published between 2010 and 2020. These documents were subjected to semantic contrast, with reference to the various dimensions and positions of human development as a generator of subjective well-being for the configuration of public labor policies. The main findings refer to the disagreement points evidenced in the two-axes dimensions of the Good Living measurement systems (mobility and safety, and cultural satisfaction within territories), an important factor being the sumak kawsay, the concept of Good Living. Sumak is fullness, the sublime, excellent, magnificent, beautiful, superior. Kawsay is life, being. However, it is dynamic, changing, and is not a passive question, and is thus not considered by the different evolutionary changes of the HDI.
\end{abstract}

Keywords: sumak kawsay; Good Living; gainful employment; subjective well-being; qualitative data analysis

\section{Introduction}

COVID-19 has unsettled billions of lives and endangered the global economy. The International Monetary Fund [1] foresees a global recession as bad as, or worse than, the one in 2009. As job losses intensify, the International Labour Organization estimates that about half of all worldwide workers are at risk of losing their livelihood. Even before the COVID-19 outbreak, it was probable that one in five countries (where billions of people live in poverty) would see their per capita income stagnate or decrease by 2020 [2]. Economic and financial shocks arising from COVID-19 (such as changes in industrial production, falling commodity exchange prices, financial market volatility, and increase of insecurity) are disrupting economic growth and heightening the risks associated with other factors.

Beyond the immediate response to the crisis, the pandemic should provide the impetus to maintain the achievements reached so far and accelerate the implementation of longpending measures in order to lead the world along a more sustainable path of development, and make global economy more resilient to future shocks, by developing an inclusive and 
sustained economic system that can drive progress, create decent jobs for all, and improve living standards (ODS-2030).

This is the reason why Good Living and subjective well-being are strategic benchmarks of the first order for their impact on human capital health and the quality of the working life of employees, in order to reach and promote successful organizations [3-5]. Moreover, in recent years, huge changes have been made in various areas of global work (economy, society, technology, and health, among others) [6], which have had an impact on how labor activity is perceived by workers [7-9].

A relevant example of how the notion of human development can be enriched occurred in the Montecristi-Ecuador Constituent Assembly, and one of the core points of the debate was when the development of the prevailing regime was questioned (Montecristi, C. A. Ecuador Republic Constitution, 2008), a discussion enriched with diverse and plural proposals that contained elements raised inside and even outside Ecuador [10-12]. There, especially from the perspective of epistemologies marginalized by history, from indigenous peoples and nationalities, the notion of Good Living or sumak kawsay (in kichwa) was raised as an opportunity to build another society based on the coexistence of citizens in diversity and harmony with nature and on the recognition of the various cultural values existing in the country and in the world [13-15]. Knowing that there may be various epistemologies linked to ancestral communities, this article uses, as an exemplary case, the notion of sumak kawsay to represent this traditional knowledge that contributes to enriching the concept of human development.

In the second half of the 20th century, the emergence of the fundamental problem of socio-environmental sustainability opened up a discursive space composed of multiple critical responses $[12,16]$. Despite this proliferation of discourse at the normative level, its implementation has not led to necessary and sufficient changes on an individual and collective scale. Humanity's production and consumption patterns remain socially and environmentally deleterious (for an up-to-date overview of the global social and environmental situation). In this context, from a Latin American standpoint, a network of transnational actors has articulated an alternative project that seeks to move away from the dominant paradigm of development and approach a new horizon: that of "Good Living and labor well-being in organizations" [9].

While jobs provide income and generate products, they also affect one's identity, shape the well-being of those who possess them, and affect the well-being of others [17]. For this reason, the Sustainable Development Goals (hereinafter the SDS) state that organizations must have strategies that support and interconnect Good Living and sustainability issues for their implementation. Therefore, different goals are put forth regarding the competencies of co-workers, sustainability thinking, and their implementation in organizations, so as to promote personal well-being and contribute to business success [18]. This poses important challenges to business agents, such as capturing and retaining their employees, nurturing them so that they can feel satisfied and develop their creativity, being committed to the organization and, in this way, helping the organization reach a state called "Good Living" - a state of well-being from which extraordinary results can be achieved-for the development of well-being in organizations [19-21]. However, the debate on the development of well-being in organizations is centered on the perception of the "development" concept.

To identify what elements should be present in the perception of development, the conventional development measurement content and the Human Development Index (HDI) of the United Nations Development Programme (UNDP) are confronted with the concept of Good Living. The aim is to generate a comparative analysis between the criteria established by the UNDP and the new theoretical positions of the ancestral ideologies' resurgence as new business management practices [14]. Therefore, the objective of this study is to provide an analytical-descriptive and synthetic contribution to a retrospective construction of Good Living through a theoretical-economic, ontological, and epistemological comparison from its dimensional axes related to subjective well-being. This work is presented from 
a qualitative perspective, of a documentary nature and with a descriptive depth level according to the objective proposed. A more detailed description of the hoisting and analysis of information is presented in the third section. The location of this description answers the need to pre-outline the conceptual elements that nurture the content of the categories with which the analytical exercise is designed.

\section{Background}

\subsection{Good Living as Subjective Well-Being}

The multidimensional character of Good Living involves great complexity when analyzed from a holistic perspective, so empirical studies on this subject are quite scarce [22,23]. This is true from the beginning of neoclassical school and its evolutionary vision of [24,25], through the Keynesian approach of [26-28] — called Latin American structuralism and neostructuralism - to finding radical positions such as those of [29-31] who, since the so-called post-development, assume currents known as degrowth and report the development for their debatable reach in the world and its findings in Latin America.

Likewise, it is proposed that the rationalities of indigenous people are not embedded in the ideologies of progress, but rather that these knowledges are sources for building alternatives to labor welfare [32,33]. In the second half of the twentieth century, the emergence of the fundamental problem of socio-environmental sustainability has opened a discursive space composed of multiple more or less critical responses [34]. Good Living or sumak kawsay is a concept that breaks from traditional paradigms [35] and focuses on the philosophy of a balanced relationship between people, their community, their well-being at work and their natural environment [36]. In other words, it is based on the responsible enjoyment of human rights while respecting common goods in the context of harmonious coexistence. Therefore, from the revision of the literature, a succinct theoretical presentation is made here about the evolution of the notion of development, which leads to consideration of the main trajectories in which this discussion has moved.

The concept of sumak kawsay, or Good Living, refers to an ancestral social phenomenon that persists today [37]. The way of life of the Ecuadorian Amazon Indigenous (kichwa, achuar and shuar), is based on the search and maintenance of harmony with oneself, with the community, with work and with other beings of nature, within the Amazon rainforest, through the combination of spiritual and material elements [38].

There are some previous works with partially similar approaches, such as the genealogy of Good Living at work [23]. However, there are some authors who disagree with this thesis because they defend the Andean origin of sumak kawsay [39,40], and others who disagree because they question whether there is a sumak kawsay in organizations as a way of life, since certain patriarchal, belligerent and predating practices of some Amazonian indigenous communities would have nothing to do with the idea of harmony with the community and nature [41]. As we will see below, the current focus on Good Living results from emerging thinking on the goals for well-being at work, which constitutes it in contemporary discourse and positions it in discursive interactions about (sustainable) development on the world stage.

\subsection{Good Living and Human Development Index}

In recent years, the invocation of Good Living has gained popularity as an alternative to classic positions about development and quality of life [35]. As an example, this spirit has been formalized in two countries, Bolivia and Ecuador, being recognized in their new constitutional texts. There are various positions on Good Living, although in them there is a desire for classical development for the human being [21]. Therefore, environmental aspects play a central role: while conventional postures are interested in material consumption and conceive of the environment as a basket of resources to be harnessed, Good Living and the rate of human development are more interested in people's quality of life, well-being at work and respect for Nature [42]. Thus, Good Living and the human development index 
imply an emerging way of conceiving the relationship with work in order to simultaneously ensure the well-being of co-workers.

Throughout recent history, development has been interpreted in different ways $[43,44]$. The Human Development Index (HDI), from its emergence in 1940 to 2005, has presented a series of conceptual and methodological changes that have caused controversy in countries' results, both in the index itself and in obtaining it [45] (Figure 1 (Evolution of Development Theory)). In 1990, the HDI was simple: the development of countries could be measured by indicators-per capita income, achievements in health and education-ranking countries according to the results of the geometric media and categorized according to their development level into very high (with levels above 0.80 ), high (levels are between 0.70 and 0.80 ), medium (between 0.50 and 0.70 ) and low (with a rating of less than 0.55) [46]. This is explained by the fact that it is a complex factor of understanding and difficult to promote; as is well known, it depends on multiple variables and relationships between them, and although the theory has tried to frame the concept, learning on the subject is evolving [47-51].

However, the United Nations Development Programme (UNDP) with the emergence of the results of the countries participating in the measurement, restructured the discourse on human development, and different indexes have been added to cover other dimensions of human development [52]. In 2010, three new indexes emerged: poverty, inequality and women's empowerment in multiple areas. Figure 1 shows some of the indicators used to measure development. Development indexes have evolved in different versions in the following chronological order: HDI in its classic version, Human Poverty Index for Developing Countries (HPI 1 and 2), Gender Human Development Index (GHDI), and Gender Empowerment Index (GEI).

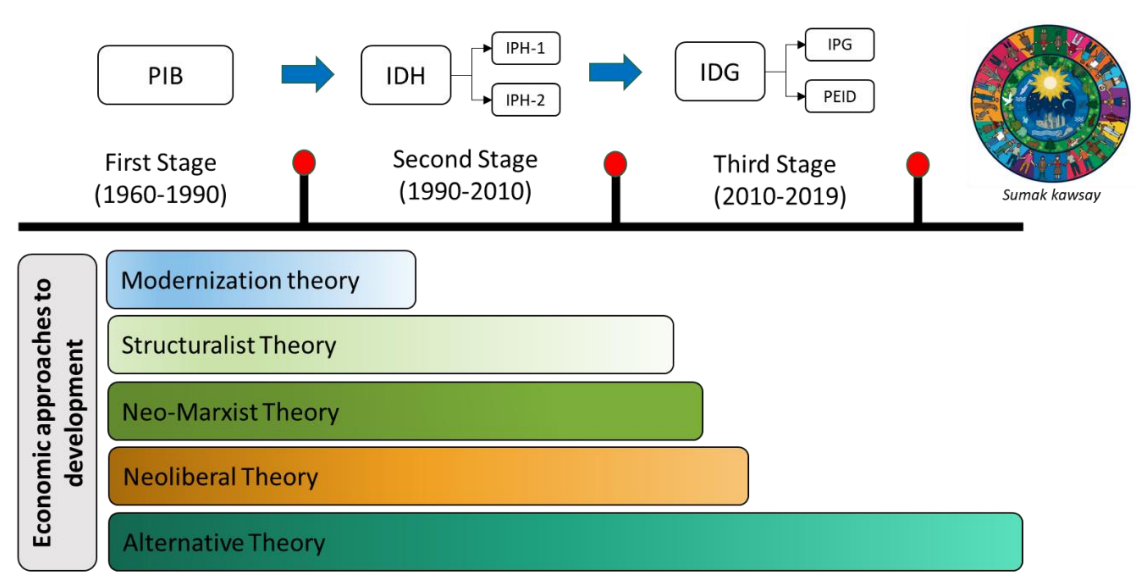

Figure 1. Evolution of Development Theory 1960-1990, 1990-2010, 2010-2019.Source: Own elaboration from [53].

On the other hand [54], two changes in measurement systems in the HDI stand out. The first is the incorporation of the HDI-d or human development index adjusted for the distribution of inequality. The second change concerns the construction of the index, which is made by combining three dimensions derived from the fundamental opportunities to achieve a good life: enjoying a long and healthy life, which is measured with the demographic indicator of life expectancy at birth; education, which measured through social indicators such as average school years and expected years of schooling; finally, the decent living standard dimension, which is measured through Gross National Income, an indicator of economic opportunities (see Table 1).

In terms of calculation, the HDI is the result of the geometric mean of each of the standard indexes that measures the achievements of each dimension (see Table 1). "[The index has a path of] 1 to 0 , where unity (1) offers an ideal situation full of opportunities for citizens. On the contrary, zero (0) denotes a situation that must be overcome or in some cases avoided" [52]. This approach defines development as a process of expanding skills 
and options so that people can be and achieve what they value. UNDP also places at the heart of its postulates the expansion of freedoms and overcoming deprivation to achieve people's aspirations [55]. This is how human beings are conceived, namely as a carrier of capacities, in terms of ends and means of development. People's capacities are strongly conditioned by economic, political, social, labor, cultural and environmental environment in which they develop [56]. Therefore, to ensure the expansion of human capacities, the definition of policies must incorporate both individual needs and collective potentials [50].

According to the thought of [57], it was understood in economic theory that the clearest manifestation of underdevelopment is expressed in a deep, complex and global indicator: the failure to cover human's costs, which are constitutive factors that allow them to live satisfactorily in a particular historical era. Consequently, Reference [57] refers to universal rights as not being linked to the employment or activity the indivual performs.

The above, according to [58], means that institutions and society are responsible for providing these rights, and the costs of humans constitute the fundamental expenses of the human status of life for each in a given group and relate to food, health, education, recreation and work; and for all these, it is necessary to increase specific institutional measures within the framework of a development economic policy. This is relevant to the Human Development Index because, since 2001, the environmental sustainability factor represented by the values of carbon dioxide emission and energy efficiency has been added as an element to consider in the assessment of human development and quality of life [58] and would then be linked to another environmental index such as the ecological footprint.

However, while it is true that UNDP has been expanding its measurement criteria regarding development with the sole objective of ensuring the quality of life of human beings [59], new, emerging positions on development in Andean countries rethink issues such as interculturality as an indispensable element for the harmonious development of society. It thereby outlines in an inclusive way the ideals of indigenous people and their way of conceiving life, in which development is no longer unique, nor universal, but plural. Development is understood as integral, capable of encompassing non-homogeneous situations to incorporate aspects from the cultural, environmental, economic, political and social. As described, the trend of HDI should deepen other dimensions of the development for proper work. They must account for the new demands for social well-being, quality of life, Good Living, well-being and decent work in contemporary society.

\subsection{Well-Being and Decent Work}

Currently, the primary purpose of the International Labor Organization (ILO) is to promote opportunities for men and women to obtain decent and productive work in conditions of freedom, equity, security and human dignity [60]. Decent work is a concept that seeks to express what should be, in the globalized world, a good job or a decent job [61,62]. Work that dignifies and allows the development of one's own capabilities is not just any job; work that is performed without respect for fundamental labor principles and rights is not decent, nor is work that does not allow a fair income proportional to the effort made, without gender or any other type of discrimination, nor is work that is performed without social protection, nor work that excludes social dialogue and tripartism [63].

In 1999, Juan Somavia-one of the directors of the ILO (founded in 1919) from the southern hemisphere presented his report "Decent Work" [64]. It introduces this concept, characterized by four strategic objectives: rights at work, employment opportunities, social protection and dialogue. However, the concept was expanded to cover other features, such as skills development, flexibility and security at work, and more recently, topics such as work and family reconciliation began to be included [65]. Each of them also plays a role in achieving broader goals such as social inclusion, poverty eradication, strengthening of democracy, integral development and personal fulfillment.

Previous research focused on the initial sociological and psychological aspects of the early literature on perceived job quality or decent work linked these concepts to job satisfaction, mental well-being, health and the emotional relevance of the collaborator, which had 
strong effects on the results of organizations [66-68]. However, in more recent literature, two perspectives have emerged [69], a more subjective one, on certain peculiarities of workers (attitudes, motivation, satisfaction, commitment, involvement and loyalty, among others), and a more objective one, related to the work environment (safety, physical and psychological conditions, social support and job stability, among others).

For its part, decent work puts the spotlight on the worker and individual working conditions [70]. In this sense, quality of employment is a component of decent work. According to [71], this double look leads to a dilemma of principle, as the first approach considers individual circumstances, including aspects of the working environment, such as the unemployment rate. However, the second proposal aims to obtain a measure of the quality of work independent of personal circumstances and labor market conditions; that is, it tries to identify the objective characteristics of work that meet the needs of the worker. For this reason, promoting these theoretical postulates drives the work to reach development goals, by 2030, to achieve full and productive employment and decent work for all women and men, including young people and people with disabilities, as well as equal pay for equal value work, which decent, sustained, inclusive and sustainable.

Full and productive employment and decent work for all directs the eradication of poverty, which is possible through steady and well-paid jobs [72]. Nearly 2.2 million people live below the poverty line of USD 2 in the United States [73]. The collection of data and statistics of labor has traditionally focused on employment and unemployment [74], with the greatest emphasis on the second of these. The revision of the development economy is making it clear that it is not enough to just generate proposals, because the volume of employment generated by an economy at any given time hardly serves us to know its characteristics, that is, how far jobs guarantee quality of life or, in other words, enhance people's capacities [75].

\section{Materials and Methods}

This section use a the interpretative hermeneutic analysis of representative documents on Human Development Index (HDI) vs. Good Living (GL) through the following stages: structuring, categorization, contrast and interpretation. To do this, qualitative data analysis (Atlas.ti8, Scientific Software Development GmbH, Berlin, Germany) was used as an approach, allowing it to extract, categorize, and link segments of data from a wide variety and volume of documents. Based on its analysis, the software helped us discover patterns $[76,77]$ Atlas.ti is qualitative data analysis (QDA) software, and its recent version is now a Windows-based application. For these authors, Atlas.ti8 provides some very useful tools in academic research, particularly for social science disciplines.

For this work, the use of software has allowed the generation of Table 2 and the semantic network. This research assumed what was raised by $[78,79]$, who agree on the schematic structure of epistemic matrix to discover and compare the development approaches through their ontological and epistemological structures. Therefore, this research considered the following levels of discussion to analyze from the scientific literature the construction of HDI with the development perspectives of VDI [80], described in Table 1.

Table 1. Epistemic Matrix.

\begin{tabular}{|c|c|}
\hline Components & Expressions \\
\hline Approach Theoretical-Economic & $\begin{array}{l}\text { This refers to several predominant economic theories in the emergence of different } \\
\text { alternatives to measure development. }\end{array}$ \\
\hline Ontological & This refers to the perception of reality in each measurement system. \\
\hline Epistemological & $\begin{array}{l}\text { This involves the way how the different cooperation agencies and/or countries conceptualize } \\
\text { the measurement systems (object of the study). }\end{array}$ \\
\hline Dimensional axes vs. Dimensions & $\begin{array}{c}\text { This is intended to compare dimensional axes (GL) with the dimensions of HDI (in their } \\
\text { different versions) }\end{array}$ \\
\hline
\end{tabular}


To establish a parallel between measurement systems, the documentary-interpretative analysis was used as a logical operation of analysis and interpretation of information, for comparison and synthesis, using the hermeneutic-interpretative method of representative texts in light of impact factor databases (Scopus and Web of Science) with the exception of official documents issued by UNDP from its technical notes and the research book of the Population and Sustainable Local Development Programme (PASLD) of the University of Cuenca, Ecuador. In this case, following logical coherence, the axes of Good Living were confronted with the dimensions of HDI in order to determine the meeting points and contrasts as the objective of this study. As Figure 2 states, the procedure for this documentary analysis consisted of the approaches to the triple process of $[80,81]$.

Communication Process

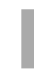

Transformation Process

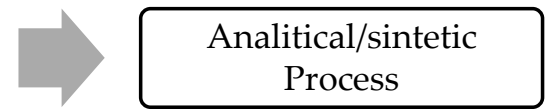

Figure 2. Documental analysis according to triple process. Source: Prepared from the triple process of [81].

An analysis and documentary contrastive process was carried out through the direct consultation of scientific articles indexed in databases with impact factor $(x>-1)$ taking into account search and selection criteria (Publication from: 2010-2020, Language: Spanish and English (analysis in English), Keywords: Good Living or Living Well, Human Development Index and Measurement Systems on Development) and turned to the systematic review of the literature [82].

With regard to the contrast of dimensional aspects, the perspective of Good Living in its six dimensional axes (democratic participation, territorial and environmental conservation, social inclusion and access to services, cultural satisfaction within the territories, social and solidarity economy, mobility and security) [10] was taken into account. Concerning HDI, the unified dimensions of the different development rates that make up its evolution (participation and democracy, environmental conservation, social inclusion and access to services and economy) $[83,84]$ were considered. Atlas.Ti8 was used as a computer tool to perform qualitative data analysis, allowing the deconstruction, organization and construction of relationships networks between categories and the structuring of significant findings. To this end, structural networks and the document code matrix were generated to analyze the basic theories on the development perspectives, to build meanings and to understand dimensional differences through theoretical triangulation between Good Living and HDI.

\section{Results}

Once the processes of bibliographic systematization described above had been implemented, the phase of contrasting the development perspectives (GL vs. HDI) was carried out. For this purpose, a summary is presented in Table 2, which synthesis the four levels of analysis previously described in the Epistemic Matrix (Table 3) [85]. The comparative analysis between the GL vs. HDI begins with a dialogue from the theoretical-economic origin. It can be found that HDI and GL suggest sharing a holistic and multidimensional ideal. It then delves into ontological aspects-i.e., it explains how both approaches conceive the nature of reality (ontology) and its relationship to measurement systems-and into how it is going to be measured (epistemological). Finally, it contrasts its dimensional axes or dimensions between (GL vs. HDI) in order to provide an analysis structure that contributes to the critical debate between development approaches. 
Table 2. Contrasting of Good Living and HDI.

\begin{tabular}{|c|c|c|}
\hline Levels & Good Living & HDI \\
\hline $\begin{array}{l}\text { Theoretical- } \\
\text { economical } \\
\text { approach }\end{array}$ & $\begin{array}{l}\text { Theories Alternatives: } \\
\text { multidimensional } \\
\text { development, sustainable } \\
\text { human development, } \\
\text { Good Living perspectives }\end{array}$ & $\begin{array}{l}\text { Structuralist Theory: } \\
\text { neostructuralism, equity, } \\
\text { development and citizenship. } \\
\text { Neoliberal Theory: } \\
\text { post-Washington Agreement. } \\
\text { Alternatives Theories: } \\
\text { multidimensional } \\
\text { development, sustainable } \\
\text { human development }\end{array}$ \\
\hline $\begin{array}{l}\text { Ontological approach } \\
\text { (Nature of Reality) }\end{array}$ & $\begin{array}{l}\text { 1.- Social harmony. } \\
\text { 2.- Political harmony. } \\
\text { 3.- Multinational and } \\
\text { intercultural harmony. } \\
\text { 4.- Harmony with nature. } \\
\text { 5.- Economical harmony. } \\
\text { 6.- Harmony with globality. }\end{array}$ & $\begin{array}{l}\text { 1.- Dignified standard of living. } \\
\text { 2.- Knowledge. } \\
\text { 3.- Social Inclusion. } \\
\text { 4.- Devolopment according } \\
\text { gender. } \\
\text { 5.- Politic Participation and } \\
\text { decision-making. } \\
\text { 6.- Environmental } \\
\text { sustainability. }\end{array}$ \\
\hline
\end{tabular}

Both approaches are emerging through alternatives theories for development with multidimensional perspectives.

\begin{abstract}
The realities perceived by UNDP through HDI in their different versions attempt to compare countries with simple indicators, examining indicators that consider the most influenced in the development of a country. On the contrary, Good Living aims to account for the harmony of the human being and its relationship with the environment, giving greater importance to subjective aspects such as happiness, which generates and good coexistence.
\end{abstract}

Despite both development perspectives try to cover multidimensionality, HDI seeks to present its dimensions in a simple way. In contrast to development perspectives through Good Living, the objective indicators would be not enough to respond to ontological aspects that arise, therefore, they generate a complexity on the item for the items for the valuation of development.

Systemic paradigm to face

the realities of the curren world are presented
Living", which represents a new way of living.
The dimensions of HDI do not dialogue with the following dimensional axes of Good Living in terms of cultural satisfaction within territories and in mobility and security. (deeper into the following setions)
Dimensional axes vs. Dimensions
1.- Participation and democracy 2.- Territorial and environmental conservation 3.- Social inclusion and access 4- - Cultural territories

5.- Social and solidary economy 6.- Mobility and security
1.- Participation and democracy 2.- Environmental conservation 3.- Social inclusion and access to services

4.- Economics

Source: prepared from the Technical Notes of UNDP Human Development Reports (2016) and data from the Population and Sustainable Local Development Programme (PYDLOS) of the University of Cuenca, Ecuador [86].

Table 3. Code document table with relative frequency in columns.

\begin{tabular}{|c|c|c|c|c|c|}
\hline & \multicolumn{2}{|c|}{$\begin{array}{l}\text { Operational Dimensions of the HDI } \\
\qquad \mathrm{Gr}=9\end{array}$} & \multicolumn{2}{|c|}{$\begin{array}{l}\text { Dimensional Axes of the Good Living } \\
\qquad \mathrm{Gr}=49\end{array}$} & \multirow{2}{*}{$\begin{array}{r}\text { Total } \\
\text { All }\end{array}$} \\
\hline & All & Column Relative & All & Column Relative & \\
\hline $\begin{array}{l}\text { Participation and Organization. } \\
\mathrm{Gr}=3\end{array}$ & 2 & $12.50 \%$ & 1 & $2.04 \%$ & 3 \\
\hline $\begin{array}{l}\text { Cultural satisfaction within the territories } \\
\mathrm{Gr}=9 ; \mathrm{GS}=7\end{array}$ & 2 & $12.50 \%$ & 7 & $14.29 \%$ & 9 \\
\hline $\begin{array}{l}\text { Mobility and security } \\
\mathrm{Gr}=10 ; \mathrm{GS}=9\end{array}$ & 1 & $6.25 \%$ & 9 & $18.37 \%$ & 10 \\
\hline $\begin{array}{l}\text { Participation and democracy } \\
\mathrm{Gr}=16 ; \mathrm{GS}=13\end{array}$ & 3 & $18.75 \%$ & 13 & $26.53 \%$ & 16 \\
\hline $\begin{array}{l}\text { Social and solidarity economy } \\
\mathrm{Gr}=9 ; \mathrm{GS}=6\end{array}$ & 3 & $18.75 \%$ & 6 & $12.25 \%$ & 9 \\
\hline $\begin{array}{l}\text { Social inclusion and access to services } \\
\mathrm{Gr}=13 ; \mathrm{GS}=9\end{array}$ & 4 & $25.00 \%$ & 9 & $18.37 \%$ & 13 \\
\hline $\begin{array}{l}\text { Territorial and environmental conservation } \\
\mathrm{Gr}=5 ; \mathrm{GS}=4\end{array}$ & 1 & $6.25 \%$ & 4 & $8.16 \%$ & 5 \\
\hline Total & 16 & $100.00 \%$ & 49 & $100.00 \%$ & 65 \\
\hline
\end{tabular}




\section{Dimensional Analysis}

Thus, in Figure 3 are observed the meeting points between both perspectives in the dimensional axes of GL and dimensions of HDI: environment, social exclusion, dignified standard of living, knowledge and a long and healthy life.

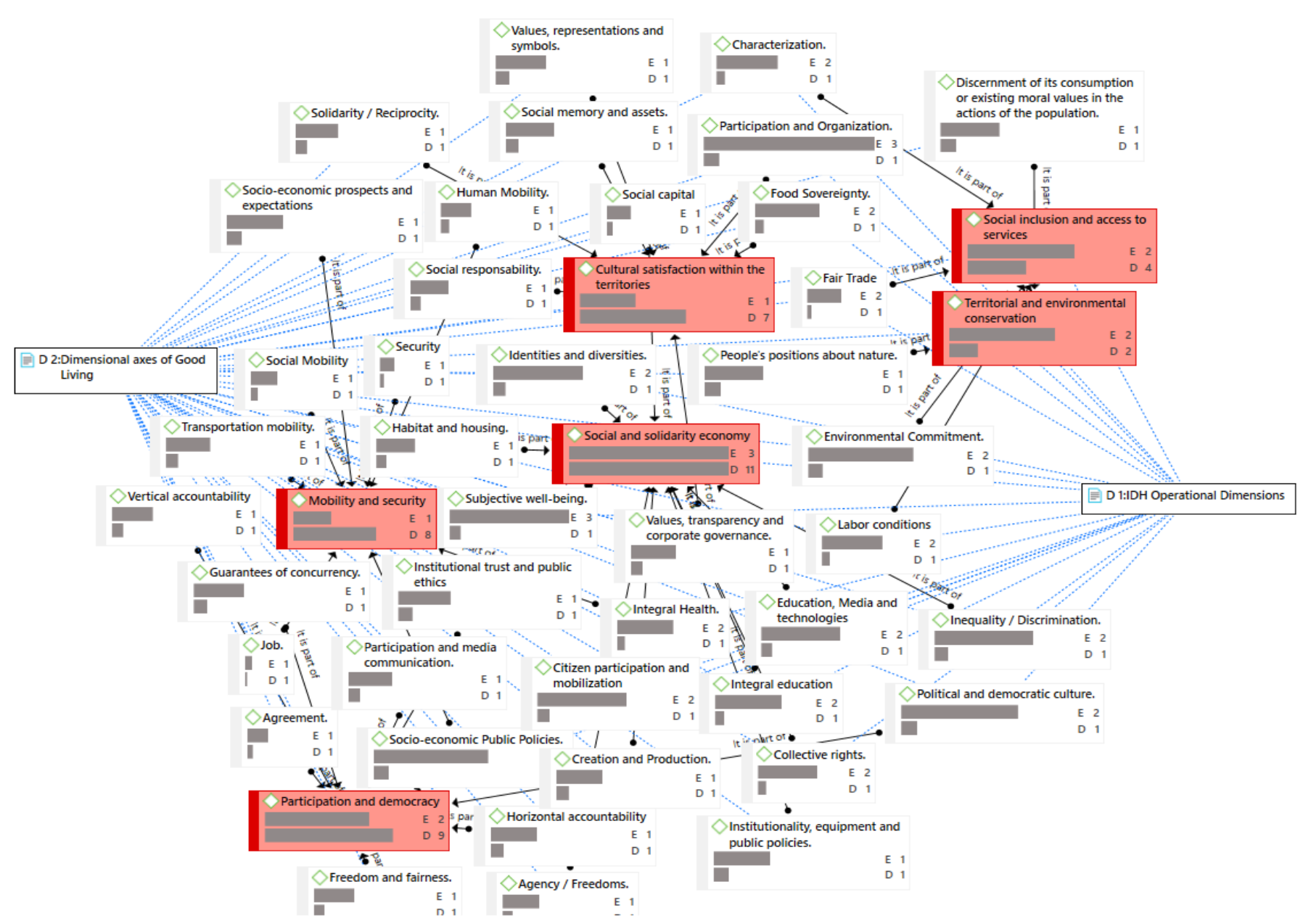

Figure 3. Comparison of dimensions between Good Living and HDI perspective through theoretical/conceptual triangulation with Atlas.Ti8.

Figure 3 shows a code-document analysis generated by AtlasTi.8, elaborated for the purpose of graphically show the relationships of dimensional axes and Good Living dimensions and how this dialogue with HDI. This allows us to identify the meeting and disagreement points between GL vs. HDI through a cross-table of code documents (See Table 3).

In Table 3 and Figure 3, the following dimensions are observed: cultural satisfaction within the territories and mobility and security are components of the Good Living that do not dialogue with HDI and its versions [14]. Specifically, the disagreement points evidenced in the dimensional convergence on the two axes of Good Living measurement systems (mobility and security and cultural satisfaction within territories) are not considered by the different evolutionary changes of the HDI [87]. Mobility and security are conceived in the perspective of Good Living as overlapping aspects under the ecological and social systems' own reality, and whose relationship is solidified according to the complexity of these ecosystems.

Therefore, migration flow is fundamental to life (mobility), and the constructive direction of flow is indispensable for the conservation of life (security) [48]. This is why these aspects are considered by Good Living as a dimensional axis, operationalized (dimensions) 
as Human Mobility (studies, rights of migration flows, multiculturalism, tolerance, discrimination, customs values), Social Mobility (Intergenerational and Intragenerational Mobility), Mobility-Transport (Transport, roads and conditions) and Security (citizen security, security of the environment and security institutionality).

Once the technical notes of the HDI have been examined, it can be considered that dimensions of "mobility and safety" considered in the measuring system of the Good Living perspective do not dialogue with the dimensions of the HDI in their different versions. However, it is important to note that, in some specific regional reports of Human Development, for example, in the 2013-2014 period, a report entitled "Citizen Security with a Human Face: Diagnosis and Proposals for Latin America" [84] was presented. Despite not being a component of HDI, it observed the intentionality by UNDP in considering these aspects as study elements that recognize mobility and safety as emerging human needs.

One of the bases of Good Living is accepting cultural differences as a dialogue of knowledge referring to the various worldviews, structured in its measurement system, including: values, representations and symbols (ethical, volitive, emotional and affective aspects), language and representations, religiosity and reflection, identities and diversities (interculturality, diversity and social dialogue, cultural awareness and relevance), cultural and artistic potential, reproduction cores and identity transition, institutionality, equipment and public policies (public policies and cultural actions, infrastructure, facilities and services, public space, cultural rights and access to the exercise of cultural citizenship).

Cultural satisfaction is a subjective element of measurement that depends on the perception of fellow citizens in terms of complex aspects such as affective and emotional. This dimensional axis is not contemplated by the different indicators of HDI, which, succinctly and objectively, aim to quantify development from an ontological and epistemological approach different from that of Good Living.

\section{Discussion}

The multidimensional character of Good Living and welfare at work involves great complexity when it comes to performing analysis from a holistic perspective, so empirical studies on this subject are quite scarce [88]. In this work, different operational dimensions and dimensional axes of Good Living and work-related well-being are built, such as participation and organization, cultural satisfaction within territories, mobility and security, participation and democracy, social economy and solidarity, happiness and satisfaction with life, trust and satisfaction with government and community, security, physical features of housing, and concern for the environment. To [89] recognizes that the proposal of the sumak kaway proposal is still unfinished and can be further perfected. Consequently, the sumak kawsay cannot be committed in the short term, nor is it a paradigm of consolidated and full development. Around these trends of multidimensional thoughts, critical positions emerge originating from indigenous peoples (Andean countries) related to Good Living [90], which contrast with classical theories about development and raise the need to re-imagine development from Latin American realities (Ecuador, Colombia, Peru and Bolivia). Such is the case of the concept of sumak kawsay, in the Quichua language, i.e., Good Living, which represents a new way of living not better than others but simply good in terms defined by culture, under a society where it is lived in harmony and with respect to planet Earth [91,92].

According to [93], the scientific literature notes that these forms of thought have been formalized through the legal systems of countries such as Ecuador and Bolivia. In the case of Ecuador, its Magna Carta of 2008 considers Good Living as a right conceived as a new way of coexistence and harmony with nature (Republic of Ecuador, Constitution of the Republic of Ecuador, 2008), which respects the dignity of citizens and society in general. In the case of the Bolivian Constitution of 2009, it reconceptualizes the term Living Well on the basis of the ethical and moral principles that the State must promote, having the the protection of nature as its main aim (Plurinational State of Bolivia, Political Constitution of the Plurinational State of Bolivia, Ministry of the Presidency, La Paz, 2009). 
The stimulus for sustainable development has been accompanied by a great debate about what needs must be developed: the economy, society or people [94]. The ancient literature on economic development and environmental protection has given way to a broader perspective of this concept that focuses on human development and people's values and objectives. Adopting a psychological point of view, References $[95,96]$ consider sustainability not only in terms of ecological and social environments but also in terms of promoting the well-being of all people. In this regard $[97,98]$ they proclaim that new human well-being measures are needed to replace the classic indicator of gross domestic product (GDP) as the main development objective at the country level. According to these authors, to understand Good Living, sustainable well-being as a new metric should incorporate ideas from the fields of ecology and human psychology. Specifically, the workplace should be explored from the point of view of positive psychology [97,99-101], which states that sustainable development can only materialize in work environments that promote health and well-being of workers. This philosophy is the basis of the European Employment Strategy, which aims to create more (quantity) and better (quality) jobs [102-104].

We believe that this study has managed to go beyond the contributions of subjective wellbeing and Good Living In the contemporary development of the notion of sustainable human development in corporate human capital [105-108], in which the of development was associated with the economic perspective during the Cold War, where industrialized countries showed the world their models of economic recovery and competed to show effective results [109-112]. Over time, theoretical discussions about development focused on accepting the assumptions of welfare economics understood as utilitarian, as a vision for maximizing the production of goods and services [113-117]. Such reasoning was challenged by human development positions, where utilitarian assumptions are displaced by a broader and more humanistic vision, where people can choose the way of life they value. Likewise, dimensions such as education, health, research and development were strengthened.

In recent years, with the emergence of indigenous peoples in politics, new ways of understanding life have been reborn in the Andean countries through the concept of Good Living (sumak kawsay), which outlines a new lifestyle that exalts coexistence in harmony with and respect for nature. This indigenous ideal obtained its booms in countries such as Ecuador and Bolivia, presenting an alternative to broaden the perspective about development, because the current ones have been insufficient to solve the current social and environmental problems, both locally and globally.

Therefore, the ways of measuring fundamental rights, such as the right to education, health, decent income and the right to a long life, share the dynamics of societies where other needs emerge and with them other conceptions about development, which have provided criteria for the formulation of new indicators to cover other human dimensions, such as poverty, inequality and women's empowerment in multiple areas.

The HDI evolved in different versions in the following chronological order: HDI in its classic version; Human Poverty Index for Developing Countries (HPI 1 and 2); Gender-related Human Development Index (GDI) and Gender Empowerment Measure (GEM); environmental sustainability factor, represented by the values of carbon dioxide emission; and energy efficiency, as an element to be considered in the evaluation of human development and quality of life [118-121].

The constant changes in human realities represented in regions, countries or continents assume theoretical-conceptual positions that shape new human dimensions for their study [122-126]. In Andean countries such as Bolivia and Ecuador, they conceive the need to be in harmony with everything that surrounds us through the indigenous idea that development is no longer unique or universal, but plural: development is understood as integral, capable of encompassing non-homogeneous situations to incorporate cultural, environmental, economic, political and social aspects that guarantee the quality of life of citizens $[121,125]$. 
From the perspective of Good Living as a new way of thinking, this paper presents a comparative analysis of the measurements of HDI and Good Living considered by the Andean countries (Bolivia and Ecuador). Dimensional gaps could be evidenced between the operational approaches of indicators of Good Living and HDI, which emphasize the aspects of cultural satisfaction within the territories and mobility and security. The comparative analysis shows that the HDI and Good Living consider participation and democracy within their measurement criteria; both are aware in their measurement systems of good democratic practices related to the participation of those involved in decision making. Likewise, territorial and environmental conservation is a determining factor for environmental sustainability and sustainability. Social inclusion and access to services are a priority to guarantee quality of life. Finally, economic aspects are an element of development in terms of production and reproduction for life.

Regarding the dimensional differences in cultural satisfaction within the territories, it was observed that the HDI does not consider aspects related to the recognition of identity and social diversity [127], citizen values, education, media and technologies represented in the public policies of the governments. Likewise, the mobility and security dimension is not contemplated, as aspects of the ecological and social systems and their relationship add complexity to this social phenomenon.

\section{Conclusions}

First, the findings provided by our research confirm, broadly, that sumak kawsay, originally an indigenous paradigm, in addition to expressing a philosophy of life, constitutes a critique of Western development as a universal, homogenizing and exclusionary model that prevails over its cultures and territories [35]. In this sense, Good Living is a proposal of indigenous resistance, which aims to be an alternative to development, for the recovery of human and natural communities and for mitigation of problems such as climate change. It stands out for its epistemological difference from rational thinking and positivist modernity, which is questioned and criticized for its colonial and reductionist character. Therefore, interpreting and conceptualizing the indigenous Good Living requires the effort to decolonize thought so that it can be understood the in terms of the relational (holistic), systemic, community and coexistence approaches that make it up, as well as the otherness character of this philosophy of life [37].

These findings are based on the need to consider the journey walked. Experiences and perspectives in the search for alternative answers, with their technical and methodological tools, are a good starting point. Innovation makes sense when it has been proven that traditional categories and indicators do not respond to social reality. However, we often do not know this, either because the traditional categories and indicators have not been explored enough or because they are unknown. If Good Living, labor welfare, poverty reduction, inequality and environmental problems were associated with the production of indicators or dimensions, the situation would probably be better; therefore, the production of indicators and indices should not be the end of this effort. The idea is to find a way to effectively use and apply these tools, in a more participatory sense, with greater democracy.

This study has expanded the limited research on the constant changes that human realities represented in regions, countries or continents bring to theoretical-conceptual ideas that shape new human dimensions for the study of development. This work presents a comparative analysis of the measurements between HDI and Good Living considered by Bolivia and Ecuador Andean countries [42]. Theoretical, ontological, epistemological, and dimensional gaps between operational approximations of indicators of Good Living and HDI were evident, which emphasize aspects of cultural satisfaction within territories and mobility and security. In this sense, both approaches are characterized by emerging through alternative economic theories for development from multidimensionality, framed in scattered realities. On the one hand, the global reality generally accepted by the United Nations countries simply responds to human development. On the other hand, particular 
regions aim to quantify through complex measurements using subjective aspects such as happiness and coexistence.

In terms of their dimensions, comparative analysis reports that HDI and Good Living consider participation and democracy among their measurement criteria; both are aware in their measuring systems of democratic good practices, related to the participation of those involved in decision-making. Likewise, territorial and environmental conservation is a determining factor for environmental sustainability. Social inclusion and access to services is a priority for quality of life assurance. Finally, economic aspects is an element for development based on production and reproduction for life. Regarding dimensional differences in cultural satisfaction within territories, it was noted that the HDI does not consider aspects of recognition of identity and social diversity, citizen values, education, media and technologies represented in government public policies. Likewise, it does not consider the mobility and security dimension, as aspects of ecological and social systems, and its relationship adds complexity to this social phenomenon. Due to the above, it emerges as a final reflection that development indicators are the product of emerging realities in a determined context and time. In other words, they are social constructs from particular understandings of those who assume the role of establishing measurement mechanisms, who, using their conceptual and cultural positions regarding development, direct their efforts towards designing complex and subjective measurement systems.

Author Contributions: Conceptualization, Á.A.-D. and D.C.; methodology, R.R.G.-D.; validation, R.R.G.-D. and G.S.-S.; formal analysis, R.R.G.-D.; data curation, R.R.G.-D.; writing-preparation of original draft, Á.A.-D.; writing-revision and editing, G.S.-S.; supervision Á.A.-D.; project administration, Á.A.-D. and D.C.; Funding acquisition. G.S.-S. All authors have read and agreed to the published version of the manuscript.

Funding: APC was partially funded by Centro Internacional de Investigación y Desarrollo (CIID) and Católica de la Santísima Concepción University.

Conflicts of Interest: The authors declare do not be any conflict of interests.

\section{References}

1. FMI Fondo Monetario Internacional. Actualización de las Perspectivas de la Economía Mundial Consultado. Available online: https:/ /www.imf.org/es/Publications/WEO/Issues/2021/01/26/2021-world-economic-outlook-update (accessed on 25 September 2020).

2. Song, L.; Wang, P.; Xiang, K.; Chen, W. Regional disparities in decoupling economic growth and steel stocks: Forty years of provincial evidence in China. J. Environ. Manag. 2020, 271, 111035. [CrossRef]

3. Lucia Casademunt, A.; Ariza Montes, J.; Morales Gutiérrez, A. Determinantas of Occupational Well-Being among Executive Women. Acad. Rev. Lat. Adm. 2013, 26, 229-257. [CrossRef]

4. Charalampous, M.; Grant, C.; Tramontano, C.; Michailidis, E. Systematically reviewing remote e-workers' well-being at work: A multidimensional approach. Eur. J. Work Org. Psychol. 2019, 28, 51-73. [CrossRef]

5. Gallegos, R.; Schobin, J.; Burchardt, H. The good and bad living of well-being / development in Germany and Ecuador. Reflections from the analysis of time. Crit. Rev. Ciências Soc. 2020, 122, 3-30. [CrossRef]

6. Temkin, B.; Ávila, S.; Martínez, E. El impacto diferencial de la globalización económica y la democracia sobre las emisiones de CO2 en países ricos y pobres. Rev. Int. Contam. Ambient. 2018, 34, 169-183. [CrossRef]

7. Khalil, E. Wellbeing and Happiness. J. Value Inq. 2019, 53, 627-652. [CrossRef]

8. Logan, H.; Cumming, T.; Wong, S. Sustaining the work-related wellbeing of early childhood educators: Perspectives from key stakeholders in early childhood organisations. Int. J. Earth Child. 2020, 52, 95-113. [CrossRef]

9. Chia, A.; Kern, M. Subjective Wellbeing and the Social Responsibilities of Business: An Exploratory Investigation of Australian Perspectives. Appl. Res. Qual. Life 2020. [CrossRef]

10. Gudynas, E. Buen Vivir: Hoy es mañana. Development 2011, 54, 441-447. [CrossRef]

11. Villalba-Eguiluz, U.; Etxano, I. Buen Vivir vs Development II: The limits of (neo-)extractivism. Ecol. Econ. 2017, 138, 1-11. [CrossRef]

12. Villalba-Eguiluz, U.; Arcos-Alonso, A.; Pérez de Mendiguren, J.C.; Urretabizkaia, L. Economía social y solidaria en Ecuador: ¿Impulsando un modelo de desarrollo alternativo? Sostenibilidad 2020, 12, 6876. [CrossRef]

13. Acosta, A. El Buen Vivir, una oportunidad por construir. Ecuad. Debate 2009, 75, 33-48.

14. Acosta, A. El Buen Vivir: Sumak Kawsay, Una Oportunidad para Imaginar Otros Mundos; Icaria: Barcelona, Spain, 2013; pp. 265-280.

15. Hidalgo-Capitán, A.; Cubillo-Guevara, A. Seis debates abiertos sobre el sumak kawsay. Íconos Rev. Cienc. Soc. 2014, 25. [CrossRef] 
16. Vanhulst, J. El laberinto de los discursos del Buen vivir: Entre Sumak Kawsay y Socialismo del siglo XXI. Polis Rev. Latinoam. 2015, 40, 36-45. [CrossRef]

17. King, P.; Waldegrave, C. Report of an Investigation into Defining a Living Wage for New Zealand; Living Wage Campaign: Wellington, New Zealand, 2012.

18. Warr, P.; Nielsen, K. Wellbeing and work performance. In Handbook of Well-Being; Diener, E., Oishi, S., Tay, L., Eds.; DEF Publishers: Salt Lake City, UT, USA, 2018.

19. Di Pasquale, E.; La operacionalización del concepto de Bienestar Social: Un análisis comparado de distintas mediciones. Obs. Labor. Rev. Venez. 2008, 1, 17-42. Available online: https://www.redalyc.org/articulo.oa?id=219016822002 (accessed on 10 October 2020).

20. Muñoz-Landázuri, M.; Sánchez-Morante, M.; Vera-Garzón, O.; Párraga-Cepeda, R. Good Living: From the indigenous and environmental proposal. Polo Conoc. 2018, 3, 399-416. Available online: http://polodelconocimiento.com/ojs/index.php/es (accessed on 15 October 2020).

21. Everingham, P.; Chassagne, N. Post COVID-19 ecological and social reset: Moving away from capitalist growth models towards tourism as Buen Vivir. Tour. Geogr. 2020, 22, 1-12. [CrossRef]

22. Dawe, G.; Jucker, R.; Martin, S. Sustainable Development in Higher Education: Current Practice and Future Developments: A Report for the Higher Education Academy. 2005. Available online: www.heacademy.ac.uk/assets/York/documents/ourwork/ sustainability/sustdevinHEfinalreport.pdf (accessed on 25 September 2020).

23. Hidalgo-Capitán, A.; Cubillo-Guevara, A.; Masabalín-Caisaguano, F. The Ecuadorian indigenist school of Good Living (sumak kawsay). Ethnicities 2020, 20, 408-433. [CrossRef]

24. Rostow, W. Las Etapas del Crecimiento Económico: Un Manifiesto No Comunista, 3rd ed.; Cambridge University Press: Cambridge, UK, 1991; pp. 30-34. [CrossRef]

25. Lewis, A. The theory of economic development, FCE. World Dev. 1958, 6, 881.

26. Prebisch, R. Five stages in my thinking on development. Pioneers Dev. 1984, 2, 175-191.

27. Sunkel, O. Del Estructuralismo al Neoestructuralismo: La, Travesía Intelectual de Osvaldo Sunkel (LC/PU B.2019/9); Comisión Económica para América Latina y el Caribe (CEPAL): Santiago, Chile, 2019; pp. 100-104.

28. Furtado, C. Development and Underdevelopment; University of California Press: Berkeley, CA, USA, 1967 ; pp. 145-148.

29. Esteva, G.; Sachs, W. Development in the Development Dictionary-A guide to knowledge as power. Popul. Dev. Rev. 1992, 1, 1-5. [CrossRef]

30. Escobar, A. Más allá del Tercer Mundo: Globalidad imperial, colonialidad global y movimientos sociales anti-globalización. Nómadas 2004, 20, 86-100. Available online: https:/ / www.redalyc.org/articulo.oa?id=105117734009 (accessed on 4 November 2020).

31. Cubillo-Guevara, A.P.; Hidalgo-Capitán, A.L.; García-Álvarez, S. El Buen Vivir como alternativa al desarrollo para América Latina. Rev. Iberoam. Estud. Desarro. 2016, 47, 30-57. [CrossRef]

32. Radcliffe, S.A. Development for a postneoliberal era? Sumak Kawsay, living well and the limits to decolonization in Ecuador. Geoforum 2012, 43, 240-249. [CrossRef]

33. Cubillo-Guevara, A. Genealogía inmediata de los discursos del buen vivir en Ecuador (1992-2016). Am. Lat. Hoy 2016, 74, 125-144. [CrossRef]

34. Cuestas-Caza, J. Sumak kawsay: El buen vivir antes de ser buen vivir. In Congreso el Extractivismo en América Latina: Dimensiones Económicas, Sociales, Políticas y Culturales; Universidad de Sevilla: Sevilla, España, 2017; pp. 356-368. Available online: https: / /hdl.handle.net/11441/74686 (accessed on 6 November 2020).

35. Mero-Figueroa, M.; Galdeano-Gómez, E.; Piedra-Muñoz, L.; Obaco, M. Measuring Well-Being: A Buen Vivir (Living Well) Indicator for Ecuador. Soc. Indic. Res. 2020, 152, 265-287. [CrossRef]

36. Ariza-Montes, A.; Arjona-Fuentes, J.; Han, H.; Law, R. Work environment and well-being of different occupational groups in hospitality: Job Demand-Control-Support model. Int. J. Hosp. Manag. 2018, 73, 1-11. [CrossRef]

37. Van Norren, D. The Sustainable Development Goals viewed through Gross National Happiness, Ubuntu, and Buen Vivir. Int. Environ. Agreem. Polit. Law Econom. 2020, 20, 1-28. [CrossRef]

38. Cubillo-Guevara, A.; Hidalgo-Capitán, A. El sumak kawsay genuino como fenómeno social amazónico ecuatoriano. Obets. Rev. Cienc. Soc. 2015, 10, 301-333. [CrossRef]

39. De Souza Santos, B. Hablamos del socialismo del Buen Vivir. Am. Mov. 2010, 452, 4-7.

40. Félix, G. El buen vivir: Un diálogo intercultural. Ra Ximhai 2012, 8, 345-364. [CrossRef]

41. Merino, R. An alternative to 'alternative development'?: Good Living and human development in the Andean countries. Oxf. Dev. Stud. 2016, 44, 271-286. [CrossRef]

42. Calvo, S.; Syrett, S.; Morales, A. The political institutionalization of the social economy in Ecuador: Indigeneity and institutional logics. Environ Plan. C Polit. Space 2020, 38, 269-289. [CrossRef]

43. Ordóñez Tovar, J. Teorías del desarrollo y el papel del Estado: Desarrollo humano y bienestar, propuesta de un indicador complementario al Índice de Desarrollo Humano en México. Polit. Gob. 2014, 21, 409-441.

44. Zhang, J. The dynamic linkage between information and communication technology, human development index, and economic growth: Evidence from Asian economies. Environ. Sci. Pollut. Res. 2019, 26, 26982-26990. [CrossRef]

45. Omrani, H.; Alizadeh, A.; Amini, M. A new approach based on BWM and MULTIMOORA methods for calculating semi-human development index: An application for provinces of Iran. Socio-Econ. Plan. Sci. 2020, 70, 100689. [CrossRef] 
46. Programa de las Naciones Unidas para el Desarrollo. Informe Sobre Desarrollo Humano 2000; Mundi-Prensa: Madrid, Spain, 2011.

47. Alarcón, D. Medición de Condiciones de Vida; Banco Interamer: Washington, DC, USA, 2001; pp. 1-21.

48. Universidad Carlos III de Madrid. Available online: http://portal.uc3m.es/portal/page/portal/grupos_investigacion/ sociologia_cambio_climatico/El\%20desarrollo\%20social\%20hoy.pdf (accessed on 19 October 2020).

49. McGillvray, M.; Clarke, M. Understanding Human Well-Being, 1st ed.; United Nations University Press: New York, NY, USA, 2006; pp. 30-46. Available online: http:/ / hdl.handle.net/10536/DRO/DU:30028707 (accessed on 12 November 2020).

50. Sen, A. El desarrollo como libertad. Gac. Ecol. 2000, 55, 14-20. Available online: https:/ /www.redalyc.org/articulo.oa?id=539/53 905501 (accessed on 15 November 2020).

51. Spolaore, E.; Wacziarg, R. How deep are the Roots of Economic Development? J. Econ. Lit. 2013, 51, 325-369. [CrossRef]

52. Programa de las Naciones Unidas para el Desarrollo. Informe sobre Desarrollo Humano. Sostenibilidad y Equidad. Un Futuro Mejor para Todos. 2011. Available online: http://hdr.undp.org/sites/default/files/hdr_2011_es_summary.pdf (accessed on 25 November 2020).

53. Bustelo, P. Economía del Desarrollo un Análisis Histórico; Editorial Complutense: Madrid, Spain, 2011; pp. 20-28.

54. Phélan, M.; Levy, S.; Guillén, A. Sistematización de índices e indicadores alternativos de desarrollo para América Latina. Rev. Temas Coyunt. 2012, 66, 175-196.

55. Doran, C.; Kinchin, I. Economic and epidemiological impact of youth suicide in countries with the highest human development index. PLoS ONE 2020, 15, e0232940. [CrossRef] [PubMed]

56. Ghislandi, S.; Sanderson, W.; Scherbov, S. Simple Measure of Human Development: The Human Life Indicator. Popul. Dev. Rev. 2019, 45, 219-233. [CrossRef] [PubMed]

57. Sen, A. Inequality Reexamined; Clarendon Press: Oxford, UK, 1992; pp. 5-10.

58. Gutiérrez, E.; González, E. De Teorías del Desarrollo Económico al Desarrollo Sustentable; Siglo XXI Editores México: Monterrey, Mexico, 2010.

59. Alkire, S.; Foster, J. Counting and multidimensional poverty measurement. J. Public Econ. 2011, 95, 476-487. [CrossRef]

60. Kim, N.; Kim, H.; Lee, K. Social Status and Decent Work: Test of a Moderated Mediation Model. Career Dev. Q. 2020, 68, $208-221$. [CrossRef]

61. Ghai, D. Trabajo decente. Concepto e indicadores. Rev. Int. Trab. 2003, 122, 125-160. [CrossRef]

62. Ribeiro, M. Contribuciones de la psicología para repensar el concepto de trabajo decente. Rev. Psicol. Organ. E Trab. 2020, 20, 1114-1121. [CrossRef]

63. Ariza-Montes, A.; Giorgi, G.; Hernández-Perlines, F.; Fiz-Perez, J. Decent Work as a Necessary Condition for Sustainable Well-Being. A Tale of Pi(i)gs and Farmers. Sustainability 2019, 11, 1051. [CrossRef]

64. Leschke, J.; Watt, A. Challenges in Constructing a Multi-dimensional European Job Quality Index. Soc. Indic. Res. 2014, 118, 1-31. [CrossRef]

65. Grimshaw, D.; Rubery, J. Intercapital Relations and the Network Organization: Redefining the Work and Employment Nexus. Cambr. J. Econ. 2005, 26, 1027-1090. [CrossRef]

66. May, B.; Lau, R.; Johnson, S. A longitudinal study of quality of work life and business performance. S. Dak. Bus. Rev. 1999, 58, 3-7.

67. Peiró, J.; Ayala, Y.; Tordera, N.; Lorente, L.; Rodríguez, I. Bienestar sostenible en el trabajo: Revisión y reformulación. Pap. Psicól. 2014, 35, 5-14. Available online: https:/ / www.redalyc.org/articulo.oa?id=778/77830184002 (accessed on 27 November 2020).

68. Van Aerden, K.; Moors, G.; Levecque, K.; Vanroelen, C. The relationship between employment quality and work-related well-being in the European Labor Force. J. Vocat. Behav. 2015, 86, 66-76. [CrossRef]

69. Díaz-Chao, Á.; Ficapal-Cusí, P.; Torrent-Sellens, J. Economic Crisis and Job Quality in Spain: A Multi-dimensional and Micro-data Empirical Approach. Soc. Indic. Res. 2016, 125, 613-633. [CrossRef]

70. Bryson, A.; Barth, E.; Dale-Olsen, H. The Effects of Organizational Change on Worker Well-Being and the Moderating Role of Trade Unions. ILR Rev. 2013, 66, 989-1011. [CrossRef]

71. Eurofound. European Foundation for the Improvement of Living and Working Conditions. Available online: https: / / www.eurofound.europa.eu/publications/report/2012/working-conditions/trends-in-job-quality-in-europe (accessed on 25 November 2020).

72. Plaça, L. Compromiso con los ODS Objetivos de Desarrollo Sostenible. Presencia 2020, 8, 1-26. Available online: https://www.un. org/sustainabledevelopment/es/economic-growth/ (accessed on 25 November 2020).

73. Rodríguez, G.; Jofré, N.; Alvarado, Y.; Fernandez, J.; Guerrero, R. Realidades alternativas como soporte para el desarrollo sostenible. Red de Universidades con Carreras en Informática. In Proceedings of the XXII Workshop de Investigadores en Ciencias de la Computación, Santa Cruz, Argentina, 7-8 May 2020. Available online: http://sedici.unlp.edu.ar/handle/10915/103730 (accessed on 28 November 2020).

74. Abou Hamia, M. Are developing countries accumulating sufficient total factor productivity to sustain their economic growth and job creation? Empirical evidence from the Middle East and North Africa region. Rev. Dev. Econ. 2020, 24, 1102-1127. [CrossRef]

75. Atitsogbe, K.; Kossi, E.; Pari, P.; Rossier, J. Decent Work in Sub-Saharan Africa: An Application of Psychology of Working Theory in a Sample of Togolese Primary School Teachers. J. Career Assess. 2021, 29, 36-53. [CrossRef]

76. Friese, S. ATLAS. ti 8 Windows Quick Tour, 1st ed.; Atlas. ti Scientific Software: Berlin, Germany, 2017; pp. 6-62. Available online: http:/ / downloads.atlasti.com/docs/quicktour/QuickTour_a8_win_es.pdf (accessed on 2 December 2020).

77. Hwang, S. Utilizing qualitative data analysis software: A review of Atlas. Soc. Sci. Comput. Rev. 2008, 26, 519-527. [CrossRef] 
78. Lincoln, Y.; Lynham, S.; Guba, E. Paradigmatic Controversies, Contradictions, and Emerging Confluences. In The SAGE Hanbook of Qualitative Research; Denzin, N., Lincoln, Y., Eds.; SAGE Publications: Washington, DC, USA, 2011; pp. 97-128.

79. Gonzalez, F. Epistemología y Ontología: Un debate necesario para la Psicología hoy. Diversitas 2009, 5, 205-225. [CrossRef]

80. Hernández-Royett, J.; González-Díaz, R. Enfoques de investigación en la contabilidad. Estrategia 2016, 2, 87-100. Available online: http:/ / estrategia.unisinu.edu.co/index.php/estrat/article/view/29 (accessed on 4 December 2020).

81. Bermeo-Yaffar, F.; Hernández-Mosqueda, J.; Tobón-Tobón, S. Análisis documental de la V heurística mediante la cartografía conceptual. Ra Ximhai 2016, 12, 103-121. [CrossRef]

82. Booth, A.; Sutton, A.; Papaioannou, D. Systematic Approaches to a Successful Literature Review, 1st ed.; Sage Publications Ltd: London, UK, 2016; pp. 245-267.

83. Martín, M. El bienestar subjetivo. Escr. Psicol. 2002, 6, 18-39.

84. Tay, L.; Kuykendall, L. Promoting happiness: The malleability of individual and societal subjective wellbeing. Int. J. Psychol. 2013, 48, 159-176. [CrossRef]

85. Bravo, L.; Barahona, C.; Gorozabel, V.; Moreira, D. Fuerza laboral femenina del sector industrial pesquero en el Sumak Kawsay (buen vivir) ecuatoriano. Cienciamatria 2019, 6, 307-325. [CrossRef]

86. Guillén, A. Exploración de Indicadores para la Medición Operativa del Concepto del Buen Vivir Buen Vivir, 1st ed.; PYDLOS: Cuenca, Ecuador, 2016; pp. 18-23. Available online: http://dspace.ucuenca.edu.ec/handle/123456789/25911 (accessed on 6 December 2020).

87. St-Jean, É.; Duhamel, M. Employee Work-life Balance and Work Satisfaction: An Empirical Study of Entrepreneurial Career Transition and Intention across 70 Different Economies. Acad. Rev. Lat. Admin. 2020. [CrossRef]

88. Arias, F.; Phélan, M. La Medición del Buen Vivir rural. Estudio de caso en el Cantón Pucará, Provincia de Azuay, Ecuador. Rev. Venez. Anál. Coyunt. 2016, 22,111-134.

89. Acosta, A. El buen vivir, una utopía por (re) construir, Retos del Buen Vivir. CIP Ecosoc. Boletín. Ecos. 2010, 11, 21-52. Available online: https: / / bit.ly/3psCtZ5 (accessed on 7 December 2020).

90. Shebell, E.; Moser, S. Planning for the Buen Vivir: Socialism, decentralisation and urbanisation in rural Ecuador. Int. Dev. Plan. Rev. 2019, 41, 473-494. [CrossRef]

91. Tortosa, J. Vivir bien, buen vivir: Caminar con los dos pies. Obets. Rev. Cienc. Soc. 2011, 6, 13-17. [CrossRef]

92. Biodiversidadla. Available online: http://www.biodiversidadla.org/Documentos/Bolivia_Como_interpretar_el_vivir_bien\# comentarios (accessed on 10 November 2020).

93. Prada-Trigo, J. The Transition to Entrepreneurial Governance in a Middle-Sized Ecuadorian City. Lat. Am. Perspect. 2017, 44, 124-139. [CrossRef]

94. Lo, A.; Liu, S.; Cheung, L.; Chan, F. Contested transformations: Sustainable economic development and capacity for adapting to climate change. Ann. Am. Assoc. Geogr. 2020, 110, 223-241. [CrossRef]

95. Di Fabio, A. The psychology of sustainability and sustainable development for the well-being of organizations. Front. Psychol. 2016, 8, 1534. [CrossRef] [PubMed]

96. Saiz-Álvarez, J.M.; Vega-Muñoz, A.; Acevedo-Duque, Á.; Castillo, D. B Corps: A Socioeconomic Approach for the COVID-19 Post-crisis. Front. Psychol. 2020, 11, 1867. [CrossRef]

97. Robert, K.; Parris, T.; Leiserowitz, A. What is Sustainable Development? Goals, Indicators, Values, and Practice. Env. Sci. Pol. Sustain. Dev. 2005, 47, 8-21. [CrossRef]

98. Burns, T. Sustainable development: Agents, systems and the environment. Curr. Sociol. 2016, 64, 875-906. [CrossRef]

99. Gomez, R.; Alonso, M.; Llamazares, M. Evaluation of job satisfaction in a sample of Spanish social workers through the 'Job Satisfaction Survey'scale. Eur. J. Soc. Work 2018, 21, 140-154. [CrossRef]

100. Ullah, F.; Wu, Y.; Mehmood, K.; Jabeen, F.; Iftikhar, Y.; Acevedo-Duque, Á.; Kwan, H.K. Impact of Spectators' Perceptions of Corporate Social Responsibility on Regional Attachment in Sports: Three-Wave Indirect Effects of Spectators' Pride and Team Identification. Sustainability 2021, 13, 597. [CrossRef]

101. Vimal, K.E.K.; Kandasamy, J.; Duque, A.A. Integrating sustainability and remanufacturing strategies by remanufacturing quality function deployment (RQFD). Environ. Dev. Sustain. 2021, 1-33. [CrossRef]

102. Noroño-Sánchez, J.G.; Nuñez-Villavicencio, M.; González-Díaz, R.R. Union ethics as a mechanism driving competitiveness in small and medium-sized enterprises. Utopía Prax. Latinoam 2020, 25, 154-173.

103. González-Díaz, R.R.; Acosta-Moltó, E.; Flores-Ledesma, K.; Vargas, E.C.; Menacho-Rivera, A. Experiential Marketing in Nonprofits: A Look at Experience Providers. Rev. Ibérica Sist. Tecnol. Inf. 2020, 36, 186-202.

104. Hernández-Julio, Y.F.; Meriño-Fuentes, I.; González-Díaz, R.R.; Guerrero-Avendaño, A.; Toledo, L.V.O.; Bernal, W.N. Fuzzy knowledge discovery and decision-making through clustering and Dynamic tables: Application in Colombian business Finance. Proceddings of the 15th Iberian Conference on Information Systems and Technologies (CISTI), Seville, Spain, 24-27 June 2020; pp. 1-5. [CrossRef]

105. Lengyel, A.; Kovács, S.S.; Müller, A.; Dávid, L.; Szőke, S.; Bácsné Bába, É. Sustainability and Subjective Well-Being: How Students Weigh Dimensions. Sustainability 2019, 11, 6627. [CrossRef]

106. Liu, S.; Yang, X. Human capital externalities or consumption spillovers? The effect of high-skill human capital across low-skill labor markets. Reg. Sci. Urban Econ. 2021, 87, 103620. [CrossRef] 
107. Zugravu-Soilita, N.; Kafrouni, R.; Bouard, S.; Apithy, L. Do cultural capital and social capital matter for economic performance? An empirical investigation of tribal agriculture in New Caledonia. Ecol. Econ. 2021, 182, 106933. [CrossRef]

108. González-Díaz, R.R.; Acevedo-Duque, Á.E.; Guanilo-Gómez, S.L.; Cachicatari-Vargas, E. Business counterintelligence as a protection strategy for SMEs. Entrep. Sustain. Issues 2021, 8, 340-352. [CrossRef]

109. Giovanelli, A.; Ozer, E.M.; Dahl, R.E. Leveraging Technology to Improve Health in Adolescence: A Developmental Science Perspective. J. Adolesc. Health 2020, 67, S7-S13. [CrossRef] [PubMed]

110. Pinilla-Roncancio, M.; Mactaggart, I.; Kuper, H.; Dionicio, C.; Naber, J.; Murthy, G.V.S.; Polack, S. Multidimensional poverty and disability: A case control study in India, Cameroon, and Guatemala. SSM Popul. Health 2020, 11, 100591. [CrossRef] [PubMed]

111. Van der Plas, E.; David, A.S.; Fleming, S.M. Advice-taking as a bridge between decision neuroscience and mental capacity. Int. J. Law Psychiatry 2019, 67, 101504. [CrossRef]

112. Gonzalez-Díaz, R.R.; Becerra-Peréz, L.A.; Acevedo-Duque, Á.E. Narco-marketing as a strategy for local tourism development. Rev. Ibérica Sist. Tecnol. Inf. 2020, 36, 71-85.

113. Patwa, N.; Sivarajah, U.; Seetharaman, A.; Sarkar, S.; Maiti, K.; Hingorani, K. Towards a circular economy: An emerging economies context. J. Bus. Res. 2021, 122, 725-735. [CrossRef]

114. Pieńkowski, D. Rethinking the concept of prosuming: A critical and integrative perspective. Energy Res. Soc. Sci. 2021, 74, 101967. [CrossRef]

115. Pokharel, R.; Bertolini, L.; te Brömmelstroet, M.; Acharya, S.R. Spatio-temporal evolution of cities and regional economic development in Nepal: Does transport infrastructure matter? J. Transp. Geogr. 2021, 90. [CrossRef]

116. Sánchez, M.; Ochoa, W.S.; Toledo, M.E.; Ordóñez, J. The relevance of Index of Sustainable Economic Wellbeing. Case study of Ecuador. Environ. Sustain. Indic. 2020, 6, 100037. [CrossRef]

117. Yamaguchi, R. Available capital, utilized capital, and shadow prices in inclusive wealth accounting. Ecol. Econ. $2020,169,106525$. [CrossRef]

118. Alkire, S. Dimensions of Human Development. World Dev. 2002, 30, 181-205. [CrossRef]

119. Andersson, K.P. Who Talks with Whom? The Role of Repeated Interactions in Decentralized Forest Governance. World Dev. 2004, 32, 233-249. [CrossRef]

120. Dasgupta, P.; Weale, M. On measuring the quality of life. World Dev. 1992, 20, 119-131. [CrossRef]

121. Veltmeyer, H. Latin America in the vortex of social change: Development and social movement dynamics. World Dev. 2020, 130, 104916. [CrossRef]

122. Grimm, M.; Harttgen, K.; Klasen, S.; Misselhorn, M. A Human Development Index by Income Groups. World Dev. 2008, 36, 2527-2546. [CrossRef]

123. Kosack, S. Effective Aid: How Democracy Allows Development Aid to Improve the Quality of Life. World Dev. 2003, 31, 1-22. [CrossRef]

124. Krishnakumar, J.; Ballon, P. Estimating Basic Capabilities: A Structural Equation Model Applied to Bolivia. World Dev. 2008, 36, 992-1010. [CrossRef]

125. Newman, B.A.; Thomson, R.J. Economic growth and social development: A longitudinal analysis of causal priority. World Dev. 1989, 17, 461-471. [CrossRef]

126. Pasha, A. Regional Perspectives on the Multidimensional Poverty Index. World Dev. 2017, 94, 268-285. [CrossRef]

127. Contreras-Barraza, N.; Espinosa-Cristia, J.F.; Salazar-Sepulveda, G.; Vega-Muñoz, A.; Ariza-Montes, A. A Scientometric Systematic Review of Entrepreneurial Well-Being Knowledge Production. Front. Psychol. 2021, 12, 848. [CrossRef] 